szerepet játszott. Az összegzés további részében az utolsó tíz év változásairól számolt be a szelzö.

A magyar regionális kutatások közül kiemelkedik a dunántúli terület vizsgálata. Az eredetileg néhány fös kutatócsoportból Európában számon tartott Intézet jött létre. Az átalakulás folyamatában nagy szerepet játszott Rúzsás Lajos, aki előtt méltán tisztelegtek kollégái és barátai. A régiót kutató, de a provincialitás veszélyét mindig elkerülő történész munkássága példamutató. A szakma szeretete, a tudományos pontosság, az eredmények továbbadása és az új generációk kinevelése tartozik a rúzsási életúthoz, melyet remélhetöleg méltón folytatnak az utódok.

\title{
AZ ÖNKORMÁNYZATOK VAGYONOSODÁSI FOLYAMATA
}

Pitti Z.-Varga S. (1995) Közgazdasági és Jogi Könyvkiadó, Budapest, 169 o.

Az elmúlt években az önkormányzati gazdálkodás és a szakmai érdeklödés középpontjába a helyi költségvetés problémái kerültek. A vagyongazdálkodást érintő kérdések közül napirenden volt természetesen a tulajdonmegosztảs mint a helyi önállóság feltételrendszere. A szerzők szándéka szerint kézikönyvként megjelenö kötet a téma fontossága, aktualitása és gyakorlati hasznosithatósága miatt is nagy érdeklödésire számíthat.

$\mathrm{Az}$ elméleti igénnyel feldolgozott témakörök a történelmi fejlödést elemzó és a mai gyakorlatot leíró részeknél, söt a lehetséges jövöbeli (változásokat) alternatívákat felvázoló fejezetekben is, széles körï információk elemzésének tapasztalatain nyugszanak. Külön dicséretes a szerzöknek az a törekvése, mellyel az elemzés alapjául szolgáló adatbázist az olvasó számára is hozzáférhetövé teszik a 26 mellékletben, a 115 . oldaltól a 169 . oldalig tartó terjedelemben. Mindezek mellett az egyes fejezetek mondanivalójának alátámasztására is sok adatot, táblázatot találunk.

Feltétlenül egyet kell értenünk a szerzökkel abban, hogy az önkormányzati szféra vagyongazdálkodása a nemzetgazdaság és az államháztartás szempontjából is fontos kérdés, hiszen már ma is az önkormányzatok tulajdonát képezi a nemzeti vagyon kb. egynegyede. (3-4000 Mrd Ft), mely az állam vállalkozói vagyonának mintegy kétszerese. A stratégiai gondolkodók azzal számolnak, hogy a következő évek tulajdoni mozgásai már a helyi társadalom érdekszférájában, az önkormányzatok körében fognak létrejönni ( I I. o.).

A nagyon rövid, de a téma szempontjából fontos mondanivalót tartalmazó történeti rész az 1870-1990 közötti időszak pénzügyi szabályozásait elemzi. Megállapítja, „...hogy az autonómiára vonatkozó elvek soha nem érvényesültek maradékta- 
lanul, egyfelöl a gyakorlatban nemcsak nehéz, de sokszor lehetetlen volt az országos és a lokális községi érdekü feladatok között választóvonalat húzni, másfelöl a gazdálkodási körülmények soha nem biztosítottak optimális finanszírozási feltételt." (13. o.) E megállapítás a községek és a városok esetében is érvényesnek tünik hosszú történelmi korszakokon keresztül, valójában napjainkig. Sajátosan tükrözik a településfinanszírozás problémáit a területi és a települési különbségek.

Az 1990. évi helyi önkormányzatokról szóló törvény a településeket jogi státusuk és vagyoni önállóságuk, sőt gazdasági elkülönülésük irányába mozditotta el - és ezt a folyamatot, vagyis a „községgé válást és a városodást a pénzügyi szabályozás is ösztönözte (pl. a községi két millió forint, a városok nagyobb összegü SZJA kiegészitése). 1994-ben már SZJA kiegészitésben részesült a városok $62 \%$-a, a községek $88 \%$-a, összességében a települések $86 \%$ a, vagyis 2692 település (40. o.).

$\mathrm{Az}$ önkormányzati rendszer elaprózott, alacsony mértékü az önkormányzati rendszer koncentrációja. Ez kisebbrészt politikai, nagyobbrészt gazdasági (gazdaságossági) következményekkel járhat (26. o.).

A könyvben részletesen elemzik a szerzök a helyi önkormányzatok költségvetésének bevételi szerkezetét, a különbözö források elosztási mechanizmusait és az egyes források súlyának, településtípusonkénti eltéréseit.

„A helyi (saját és átengedett) bevételek aránya 1990-ben 46\%-ról indult és 41\%on nyugszik meg 1995-ben. Sokak szerint ez rendkívül kevés, mert - ezzel szemben - az állami támogatás magas részaránya az önkormányzatoknak a központi költségvetẻstől való erős függőségét idézi elő." (50. o.). A szerzök véleménye, hogy „.... a függőség valóban erős, de nem a központi költségvetéstöl, hanem az ország (a nemzetgazdaság) anyagi erejétöl..." (50. o.). Ugyanakkor a jelenlegi onkormányzati struktürában a feladatokhoz viszonyitottan kevés pénzt is gazdaságtalanul hasznositjík.

A helyi önkormányzatok GDP-n és államháztartáson belüli részesedése a feladatok növekedésével nem változott megfelelö arányban, 1995-ben a GDP-n belüli részarányuk 15\% (mely megközelítöleg egyezik az 1990. évi részaránnyal), az államháztartási mérlegben pedig a szféra $22 \%$-os részaránya kisebb, mint volt az elözö években, ami jelzi, hogy ,,...az államháztartáson belül is visszaesett az önkormányzati gazdaság részesedése..." (51. o.).

Köztudott, hogy az újraelosztás az önkormányzati szférában preferálta a kistelepüléseket, a községeket és relative háttérbe szorította a megyéket. Fontos figyelmeztető megállapitás, hogy ,...a községeknek az országos fejlesztési kiadásokból való részesedése jóval nagyobb, mint a kiadások egészéböl, vagy ezen belül a folyó (müködési) kiadásokból való részesedése." (52. o.) Ugyanakkor a szerzök szerint valószinüsithetö, hogy a múködési gondok a későbbiekben jelentkezni fognak.

A könyv nagy érdeme, mondhatnám újszerủsége, hogy az önkormányzatok gazdasági alapjainak elemzése mellett foglalkozik a gazdálkodás rendjének kérdéseivel, igy a tervezéssel, a számvitellel, valamint az ellenörzéssel. 
A szerzök különös szerepet tulajdonítanak a fogalmi meghatározásnak, különösen az önkormányzati vagyont illetően. Álláspontjuk szerint az önkormányzati vagyon fogalmát a hatályos törvények szellemiségéböl (Ötv., számviteli törvény, vagyonátadási törvény) a piac által diktált értékítéletböl, a gazdálkodás módosult pénzügyi feltételeiből, valamint a helyi közösségek igényeiböl kiindulva lehet közelítö pontossággal - meghatározni. Ugyanitt az alábbi definíciót adják (56, o.):

„Az önkormányzati vagyon a település(ek), illetve a megye közösségének kizárólagos tulajdonában lévỏ immateriális javak, tárgyi eszközök, befektetett pénzügyi eszközök, valamint készletek, követelések, értékpapírok és pénzeszközök értékének - tartozásokkal csökkentett összege, amelyek a közösség által választott testület(ek) döntésétöl függően lakossági ellátásra igénybe vehetök, vagy a közösség felhatalmazásával a törzsvagyon kivételével - vállalkozási célra mobilizálhatók, vagy a piacon adásvétel tárgyát képezhetik." A definíciónak fontos eleme, hogy felhívja a figyelmet a vagyon összetett jellegére, annak nettó módon történő értelmezésére (kötelezettségekkel csökkentett eszközérték!) és a használat során történö, vagy a piac minösítése szerinti értékelésre.

E szemléletmód gyakorlati alkalmazásával elemzik a szerzők a vagyon összetételét és megállapitják, hogy „A vagyon mint eröforrás komoly szerepet játszik a helyi közösségek megerösődésében, eszközrendszerük bővư lésében. Talán nem túlzás azt a következtetést inegvonni, hogy kialakulóban van egy olyan helyzet, amelyben a települési szolgáltatások színvonala - mind több helyen - már nem az állami támogatások volumenétől, hanem a saját gazdálkodás eredményességétől fủgg. Véleményem szerint ez ma még kissé túlzó megállapítás éppen a saját bevételi források korlátozottsága, az állami támogatások részaránya és a túlzott mértékü központi adóteher miatt. Természetesen fontos a jövőbeli változások szempontjából, hogy a saját gazdálkodásban rejlö lehetőségeket feltárják az önkormányzatok, amennyiben a központi szabályozás bevételorientált jellege hosszabb távon is garantált és a kötelező feladatok ellátásához a finanszírozási feltételek is stabilabb gazdálkodási kereteket teremtenek.

$\mathrm{Az}$ önkormányzati vagyon strukturális jellemzöit elemezve a számviteli kategóriák szerinti sajátosságok közül fontos megállapítás, hogy a vagyon dinamikus növekedése és a vagyonstruktúra átalakulása azért is figyelmet érdemel, mert „....az értékpapirok megjelenése és a részvénycsomagok és üzletrészek uralkodó vagyonelemmé változása az önkormányzati gazdálkodás stratégiai jelentóségü változását sejtetik. Ma még a forrásoldal legjellemzöbb sajátossága, hogy az önkormányzati saját források magas mutatói elsődlegesen a gazdálkodás költségvetési jellegét (a közfeladatok ellátásának biztonságigényét) hangsúlyozzák, de közvetetten az önkormányzati gazdálkodás zártságát is jelzik, hiszen a külsö források (legyenek azok szállitói teljesítések, kötvénykibocsátások, kereskedelmi hitelek) ma nem juthatnak számottevõ szerephez..." (67. o.).

$\mathrm{Az}$ önkormányzati vagyon értékelése terén számtalan feladatot jelölnek meg a szerzök - az információs rendszertöl a döntési jogkörök szerinti vagyonértékelés 
kérdéséig, illusztrálva az ezekkel kapcsolatos problémákat a becslési eljárásokon alapuló adatokkal kapcsolatban (16. sz. melléklet, 143. o.). „A számadatok egyértelmüen jelzik, hogy a törzsvagyon alulértékelt." (68. o.). Mindezek mellett a területi és telepulési különbségek kezelése, a hazai kiegyenlitö rendszer hatókörének bővitése és hatékonyságának növelése sem tủr halasztást, mivel nélküle a vagyonnal (kiegészítő jövedelemmel) nem rendelkezö önkormányzatok behozhatatlan hátrányba kerülnek. A számviteli törvény elöirja a vagyonértékeléssel kapcsolatos feladatokat, melynek jelentős része az önkormányzati szférában még nem megoldott (pl. az egy évnél hosszabb ideje birtokolt értékpapírok piaci árfolyamon történő értékelése és nyilvántartása). Egyre inkább tudatosul az önkormányzati szférában, hogy a vagyonból származó elönyök mellett komoly kötelezettségek is megjelennek a gazdálkodás terén.

A „vagyonosodás” egyfelől az önkormányzatok mozgásterének bóvülését, másfelöl gazdálkodási felelósségük növekedését eredményezte. A legföbb kérdés most a vagyongazdálkodás adottságainak számbavétele, a vagyonnal járó kötelezettségek feltérképezése, majd a kezelési és Inúködési stratégia kialakítása. Ennek során minimál program - a szerzők megfogalmazása szerint - a vagyonvesztés elkerulése, maximált program a vagyon hasznosítása révén pótlólagos jövedelemhez jutni (ami részben a müködés feltételeit javithatja, részben további tôkefelhalmozás forrása lehet.) Az önkormányzati vagyongazdálkodás legizgalmasabb kérdése, hogy az 1990-94. évi vagyonosodás egy múló időszak, vagy egy új fejlödési periódus kezdete? (76. o.)

„Halaszthatatlanul szükség van a vagyongazdálkodás makroszintủ filozófiájának kialakitására, az elmaradt jogi és pénzügyi szabályozás pótlására, majd a központi elvek és a helyi sajátosságok figyelembevételével az önkormányzati vagyonrendeletek átfogó megújitására. Enélkül nem várható, hogy megmozdul az önkormányzati vagyon, mozgás nélkül viszont a vagyon nem gyarapodik, hanem fogyni fog." (79. o.). Mindezek szervezeti, személyi, információs, technikai feltételeinek elvi és gyakorlati kérdéseit is elemzik a szerzök.

Külön figyelmet szentelnek a könyv irói az amortizáció kérdésének mint a vagyonstabilizáció eszközének, mely különösen fontos azért, mert az elszámolt, relatíve nagyon alacsony amortizáció mellett a valóságos vagyonpótlás még kisebb. Ma ugyanis az amortizációt (melynek kulcsa is alacsony!) az általában irreálisan alacsony könyv szerinti érték alapján kell elszámolni és nem az eszköz reális újrabeszerzési értékén. „A jövőben az önkormányzatoknak maguknak kell gondoskodniuk az értékvesztő vagyon pótlási fedezetéröl, mely csak akkor teljesülhet, ha megtörténik az önkormányzati vagyon felértékelése, ha kialakul az önkormányzatok sajátosságait figyelembe vevö amortizációs rendszer." (89. o.).

A vagyonkezelés és hasznositás lehetséges modelljei címet viseló fejezetben (95103. o.) az önkormányzatok által választható vagyonkezelési lehetôségek, illetve vállalkozási formák tipusait tekintik át a szerzök, érintve a szervezeten belüli, szervezeten kívüli, illetve a kettő kombináció- 
ján alapuló lehetséges megoldások elönyeit-hátrányait.

$\mathrm{Az}$ önkormányzati szabályozás és a vagyongazdálkodás jövője függ a közigazgatási és az államháztartási rendszer korszerüsítésének irányától, a helyi adózás továbbfejlesztésétől, a vagyonosodási folyamat jövőbeni eseményeitől.

„A végsö válasz attól függ, hogy az országos irányitás tud-e megfelelö szakmai segitséget adni az önkormányzatok felkészüléséhez, illetve hogy az önkormányzatok képesek-e biztositani a rendelkezésükre bocsátott vagyon megóvását, s képesek-e különbséget tenni mai és holnapi érdekeik között (111. o.).

A rövid távú feladatok között legfontosabb teendö a vagyon induló állapot szerinti értékének megóvása, az önkormányzati vagyon (át)értékelése, az amortizációs rendszer megújitása és egy hatékony kiegyenlítỏ mechanizmus kialakitása.

A hosszú tóvú feladatok között kiemelhetỏ a vagyon racionális müködtetése, mely komoly tartalék lehet az önkormányzati források bővitésében. Mindehhez ki kell alakítani az önkormányzati sajátosságoknak megfelelö vagyonértékelési módszereket és fontos hasznosítani a külsö (szerződéses) vagyonkezelök tapasztalatait.

Az ebben rejlö lehetöségek hasznosítása kétirányú közeledést igényel: az önkormányzatoknak tudatosan kell oldaniuk a külső szervezetekkel szembeni bizalmat lanságukat, másrészt a potenciális vagyonkezelöknek is tudatosan kell készülniük nem taktikai, hanem stratégiai megfontolásból - az önkormányzati sajátosságok megismerésére, mely ma még az önkormányzati szférán belül sem eléggé ismert és feltárt területe a gazdálkodásnak (111. o.).

A vagyongazdálkodás terén valójában a tét nem kicsi, annak kell elejét venni, hogy a szabályozatlanságra, vagy a szakszerútlen gazdálkodásra hivatkozással az önkormányzati vagyon egy múló gazdaságtörténeti emlékké váljon (112.0.).

$\mathrm{Az}$ önkormányzati gazdálkodás ugyanis fontos elágazási ponthoz érkezett: „...meg kell újítani a hagyományos költségvetési gazdálkodást, de a közösségi tulajdon birtokában meg kell tanulni a vállalkozói logikára épülö döntési mechanizmust is." (112. o.).

$\mathrm{Az}$ önkormányzatok vagyonosodási folyamatát elemző és a vagyongazdálkodás széles körü kérdéseit tárgyaló könyv úgy az elméleti, mint a gyakorlatban dolgozó szakemberek számára fontos kézikönyv lehet.

Megismerése és a benne felvetỏdő kérdések továbbgondolása a gazdaságpolitika, a gazdasági szabályozás és a kutatás számára is lényeges feladatokat jelöl ki, ugyanakkor jól hasznositható az önkormányzati döntések elökészítésénél és az oktatásban egyaránt.

László Mária 